\title{
Reconstructing the Early History of Two Kabbalistic Manuscripts from El Escorial Library
}

Javier del Barco

Centro de Ciencias Humanas y Sociales (CSIC, Madrid)

Some time ago, after I had finished drawing up the Catálogo de manuscritos hebreos de la Comunidad de Madrid ${ }^{1}$ I was invited to give a talk on the Kabbalistic manuscripts held in the libraries included in that catalogue. ${ }^{2}$ I realized to my surprise that there were only two manuscripts completely devoted to the Kabbalah. Both are held at the Library of El Escorial, whose collection of Hebrew manuscripts is the most important in Spain; both entered that library in 1599, having been brought from Italy by Benito Arias Montano; ${ }^{3}$ and both contain collections of different Castilian Kabbalistic works by various authors. ${ }^{4}$

A quick glance at the two manuscripts demonstrated that, although produced in Italy, they had been copied by Sephardic hands during the first half of the sixteenth century, which meant that they were products of the cultural milieu that arose in certain parts of Italy upon the arrival of massive numbers of Jews expelled from the Iberian Peninsula. ${ }^{5}$ This paleographical evidence led me, at first, to consider both manuscripts as cultural products with similar characteristics, because of the circumstances of their production and the type of works they contain. I then proceeded to study both manuscripts with a view to answering the following questions: How were they produced? Did the selected contents in each case reflect a pre-conceived idea? Who might have selected and/or read the works? In what context, and why were the works copied and read in the Italy of the first half of the sixteenth century? The following will provide answers to these questions and thereby contextualize the production

\footnotetext{
* This article is a thoroughly revised and extended version of a paper presented at the Ninth Congress of the European Association for Jewish Studies, held in Ravenna, Italy, in July 2010. Both the paper and this article are the result of research carried out within the framework of the project INTELEG (Intellectual and Material Legacies of Late Medieval Sephardic Judaism). This project is headed by Prof. Esperanza Alfonso and funded by the European Research Council through the "Ideas" program of the VII Frame Program of the European Union.

${ }^{1}$ Francisco Javier del Barco del Barco, Catálogo de manuscritos hebreos de la Comunidad de Madrid, 3 vols. (Madrid, 2003-2006).

${ }^{2}$ The Kabbalah started to develop in medieval Iberian Judaism from the thirteenth century onwards, amidst an important ideological debate between philosophical rationalism and religious tradition (or anti-rationalistic reaction). The bibliography on Jewish Kabbalah and mysticism is extraordinarily abundant. Among the countless monographs and articles on the topic, special mention should be made of the numerous key works by Gershom Gerhard Scholem and Moshe Idel. Several bibliographical collections exist, e.g. Gershom Gerhard Scholem, Bibliographia Kabbalistica (1927) and Sheila A. Spector, Jewish Mysticism: An Annotated Bibliography on the Kabbalah in English, Garland Reference Library of Social Science, 210 (New York, 1984). An updated selection can be found in the bibliography compiled by both Scholem and Idel in the Encyclopedia Judaica, 2nd. ed. (Detroit, 2007), s.v. "Kabbalah."

${ }^{3}$ Arias Montano was commissioned by King Philip II to acquire Hebrew manuscripts in Italy and the Spanish Netherlands in order to enlarge the collection of manuscripts for the then recently built El Escorial library.

${ }^{4}$ El Escorial, Real Monasterio de San Lorenzo, MSS G-IV-10 and G-III-14; see brief initial descriptions of these manuscripts in del Barco, Catálogo, 3: no 182, 208-209, and no. 183, 210-11.

${ }^{5}$ The arrival of Sephardic Jews in Italy radically altered the social and cultural panorama of the communities in that country. For the role of the most outstanding Jewish families in this new panorama, see Elliott Horowitz, "Families and Their Fortunes: The Jews of Early Modern Italy," in Cultures of the Jews: A New History, ed. David Biale (New York, 2002); 573-636.
} 
and use of two apparently similar manuscripts that came to rest on the shelves of the Library of El Escorial. Nevertheless, I cannot pretend that the study of only two manuscripts serves per se as a representation of the Kabbalistic works read and copied in Renaissance Italy, as this can only be tested by comparing what we find in these two codices with a much greater amount of material.

A medieval manuscript can be considered as a transmitter of knowledge and as a material object with different possible uses: political, religious, artistic, and social. ${ }^{6}$ Today manuscript scholars recognize that a comprehensive study of the material aspects of medieval manuscripts is necessary in order to understand their production process and use. The first step in the study of the two El Escorial Kabbalistic manuscripts should clearly be a codicological analysis, which could shed light on how and why the Kabbalistic works they contain were transmitted, and elucidate the historical and cultural contexts in which they were produced and circulated. The answers we obtain, however, may not necessarily be representative of the cultural environment of Italian Jewish communities in the first half of the sixteenth century. ${ }^{7}$

\section{El Escorial, Real Monasterio de San Lorenzo, MS G-IV-10}

This Kabbalistic manuscript was written on paper and is the work of a single scribe. It is a small-format codex $(210 \times 145 \mathrm{~mm}$.) consisting of six quaternions or quires of four bifolia $(I V+I V+I V+I V+I V+I V)$ and is copied in a single type of semi-cursive Sephardic script. ${ }^{8}$ Due to its modest size and irregular script, we can hypothesize that it was not commissioned by a patron, but was instead a copy that the scribe, who was probably an educated person, had made for himself.

Like most Hebrew manuscripts in the library of El Escorial, it was somewhat damaged in the fire that took place in $1671,{ }^{9}$ and was subsequently rebound. It may have been while the book was being rebound that the last folio, containing the colophon, was separated from the manuscript. This loss was most likely due to the fact that it was not an integral part of the last quire, but rather a single leaf added at the end. This missing leaf was rebound at the beginning of another manuscript (El Escorial, MS G-IV-1), where it is presently folio 1. In addition, folio 1 of MS G-IV-10 does not belong to the same codicological unit as the rest of the manuscript. It was added to the beginning of the codex, and contains a text written by a different scribe and is unrelated to the other works in the manuscript,${ }^{10}$ as it comprises a

\footnotetext{
${ }^{6}$ The medieval manuscript is both unique and multifaceted, in that it performs various functions: didactic, aesthetic, historical, and political. Its study has to be approached comprehensively, with an examination of this object from all points of view; see Paul Géhin, ed., Lire le manuscrit médiéval (Paris, 2005), 6.

${ }^{7}$ As Bonfil advises: “ . ... the use of literary works as historical evidence, that is, a criterion for testing a given cultural ambiance, requires great caution." See Robert Bonfil, Rabbis and Jewish Communities in Renaissance Italy, trans. Jonathan Chipman (London, 1993), 272. On the history of the Hebrew book in Renaissance Italy, see Joseph R. Hacker and Adam Shear, eds., The Hebrew Book in Early Modern Italy (Philadelphia, 2011). ${ }^{8}$ The terminology used to denominate the Hebrew scripts is taken from Malachi Beit-Arié, Hebrew Manuscripts of East and West: Towards a Comparative Codicology (London, 1993), and The Makings of the Medieval Hebrew Book: Studies in Palaeography and Codicology (Jerusalem, 1993).

${ }^{9}$ See Gregorio de Andrés, La Real Biblioteca de El Escorial (Madrid, 1970), 15-16.

${ }^{10}$ Other folios and quires of Hebrew manuscripts suffered a similar fate after the fire of 1671, since many codices were partially damaged. The reorganization and rebinding of works that was then carried out throughout the eighteenth century under the supervision of Antonio San José, who was appointed librarian in 1725, aimed to reconstruct the most badly damaged codices, but the monks had neither sufficient means nor knowledge of the Hebrew language and palaeography to make adequate restorations in every case. Some manuscripts were reassembled with the quires bound in the wrong order, or upside down. As a result, many folios were mistakenly inserted in manuscripts to which they had never previously belonged. This disordering was also the case for MS G-I-9 (fols. 337 to 344 and fol. 347 bound upside down, many misplaced folios, and seven folios from this manuscript preserved in a folder kept with others containing folios and quires from different manuscripts, all of them under the shelfmark G-I-13); MS G-IV-7 (fols. 61 and 62 bound upside down); and MS G-IV-8 (various
} 
section from chapter eight of Shelomoh Alkabetz's commentary on the Song of Songs, Ayelet Ahabim. ${ }^{11}$ Nonetheless, excluding folio 1, this codex represents a formal codicological and palaeographic unit. ${ }^{12}$ Its scribe lived in the first half of the sixteenth century, as can be inferred from the date of 1529 provided in the colophon on the leaf rebound in MS G-IV-1. From the evidence of this date, and since the manuscript pertains to a lot that was purchased in Italy by Arias Montano, ${ }^{13}$ we may surmise that the scribe, either born in the Iberian Peninsula or a descendant of emigrant Sephardic Jews, carried out his work in Italy, where a large number of Jews who had been expelled from Castile and Aragon in 1492 eventually settled. The colophon (see fig. 1), in addition to the very explicit date, supplies additional information that calls for analysis: ${ }^{14}$

Finished and completed on the $12^{\text {th }}$ of Kislev of the year 5289 (1529 C.E.) This is my name for eternity: yod-he with the letters of the word "my name" adds up in gematria to 365, which are the days of the solar year; waw-he with the letters of the word "my remembrance" adds up in gematria to 248 , which are the parts of the human body.

What comes after the date seems to be an encoded text that, using gematria, conceals or hides the name of the scribe: thus its opening words "this is my name." The reference to the number 248 might hide the second name of the scribe, since this is the number that results from adding up the value of the letters in the name Abraham. ${ }^{15}$ The relation of the number 365 with a proper name seems more complicated. Only appellatives of the type העמרמי, or double names, might be suggested. ${ }^{16}$ Such a hypothesis yields an unsatisfactory result since it provides a proper name in the second place of the sequence, instead of a structure composed of a proper name followed by a patronymic, which is far likelier.

The key to what the scribe expresses may lie in the letters used for gematria. The phrase "this is my name for eternity" that can be read after the date refers, in my opinion, to God, which would fully justify the reference "for eternity." God's name is divided into two parts: the first part, yod-he, together with the letters of the word "my name" adds up to 365, which equals the number of negative commandments as well as the number of days in the (solar) year; the second part, waw-he, along with the letters of the word "my remembrance" adds up to 248, equalling the number of positive commandments as well as the number of parts of the human body. According to this reading, the eternal name of God is the beginning and the end of the law in a Jew's life, as represented by the 613 commandments, which are

loose folios and several misplaced folios). See the descriptions of these manuscripts in del Barco, 3: nos. 143, 144,147 , and 159 , respectively.

11 The author's grandfather was Shelomoh ben Moshe ha-Levi Alkabetz, printer of the first dated Hebrew book published in Spain (Guadalajara, 1476). See Semen Mordukhovich Iakerson, Catalogue of Hebrew Incunabula from the Collection of the Library of the Jewish Theological Seminary of America, 2 vols. (New York, 20042005), 1:xxvi.

${ }^{12}$ By codicological unit is understood "[le] volume, partie de volume ou ensemble de volumes dont l'exécution peut être considérée comme une opération unique, réalisée dans les mêmes conditions de lieu, de temps et de technique;"see Denis Muzerelle, Vocabulaire codicologique:Répertoire méthodique des termes français relatifs aux manuscrits (Paris, 1985), s.v. "Unité codicologique." The French edition, together with the Spanish and Italian editions, and the translation of terms into English, are available online at http://vocabulaire.irht.cnrs.fr/vocab.htm.

${ }^{13}$ This manuscript belongs to the same lot as G-III-14, of undoubted Italian origin. They both come from Arias Montano's collection of manuscripts and were acquired by the El Escorial library in 1599.

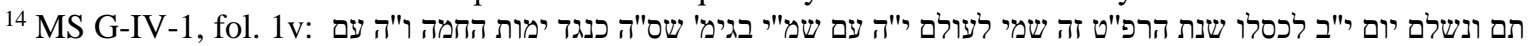
זכר"י תבוא בגימ' רמ"ח עמיז כנגד איבריו של אדם

15 This was my own opinion until recently; see also the description of this manuscript in the catalogue of the Institute of Microfilmed Hebrew Manuscripts at the Jewish National and University Library of Israel, http://aleph.nli.org.il/F/?func=file \&file_name=find-b\&local_base=nnlmss.

${ }^{16}$ I would like to thank both Colette Sirat and René-Samuel Sirat for their suggestions in this regard. 
thus recorded in the name of God and emphasize his perfection. Such a use of gematria in the colophon speaks not only of an educated person, but also of someone belonging to a group or circle devoted to the study and transmission of Sephardic Kabbalah.

The texts in this manuscript demonstrate the scribe's precise interest in one of the most characteristic elements of Jewish mysticism: the theory of the ten sefirot. The unknown author of the Sefer yetzirah (one of the first and most fundamental works on Jewish Kabbalah composed between the second and fourth centuries C.E.) had coined the term "the ten sefirot" (from the root $s-f-r$, "count, number") in reference to the ten fundamental or ideal numbers. However, the Kabbalah produced in the Iberian Peninsula during the Middle Ages and in Palestine after the fifteenth century opened up the meaning of sefirot, which began to designate the ten moments of emanation that emerged from the infinite and that constitute the sphere for the manifestation of God in his different attributes. ${ }^{17}$

The main part of this manuscript, from fol. 12 until the end (fol. 46), is a commentary on the Sefer yetzirah bearing the title Meshovev netivot ${ }^{18}$ (see fig. 2) by Shemuel ibn Sa'adia ibn Motot, a fourteenth-century author from Guadalajara. Preceding this commentary are the following works: a text entitled Sod eser sefirot belimah on the ten sefirot written by Moshe de León, the author of the core of the Zohar and the most significant author of Castilian Kabbalah (between fols. $2 \mathrm{r}$ and $7 \mathrm{v}$ ); an untitled treatise on the sefirot that was copied from a manuscript where the work was incomplete, ${ }^{19}$ whose author might be Shem Tov ibn Shem Tov, a Kabbalist known for writing a piece on the sefirot (fols. $8 \mathrm{r}-9 \mathrm{v}) ;{ }^{20}$ and a series of Kabbalistic notes finishing with two magical elements: first, the representation of a magical alphabet said to be the alphabet that was used to write the Tables of Law that God gave to Moses in Sinai; and second, a magical invocation to God and to the angels (see fig. 2) (fols. $10 \mathrm{r}-11 \mathrm{v})$.

The contents of this manuscript, therefore, seem to follow previously established criteria of logical sequence: a commentary on the Sefer yetsirah, a work that establishes the theory of the ten sefirot, is introduced by related texts: first, a Kabbalistic work by Moshe de León about those ten sefirot; second, a treatise on the sefirot that might be attributed to Shem Tov ibn Shem Tov; and finally, various Kabbalistic notes also relating to the sefirot. This indicates that this manuscript was conceived and copied as a unit of production and was intended to be circulated and read in the format in which we now find it. ${ }^{21}$

Given the coherence of this manuscript's contents we must ask for what reason and under what circumstances a Jew of Sephardic origin might have copied thirteenth- and fourteenth-century works of Castilian Kabbalah in early sixteenth-century Italy. We cannot argue that these works were copied in order to make them known in a flourishing cultural center such as the Italian peninsula at that time, since as far back as the thirteenth century the then-new ideas of the ecstatic Kabbalah had already circulated in the south of Italy, especially

\footnotetext{
17 This mystical aspect of the Kabbalah cannot be understood without the dissemination and knowledge of Islamic mysticism and neo-Platonism among successive generations of Jewish philosophers and Kabbalists, not only in Al-Andalus but also in Christian Iberia.

18 This commentary on the Sefer yetzirah belongs to a trilogy, unpublished to date, of three philosophicalKabbalistic commentaries; besides Meshovev netivot, written in 1370, the trilogy includes the work Megaleh amuqot (a commentary on Exodus), and Tehilot Adonai (a commentary on the siddur).

${ }^{19}$ As indicated by the scribe himself: MS G-IV-10, fol. 9v: לא מצאתי יותר; i.e. "I did not find anything else."

${ }^{20}$ However, his authorship has yet to be confirmed by the collation of this manuscript with the other two, also Sephardic, in which Shem Tov ibn Shem Tov's treatise on the sefirot is preserved: London, British Library, Add. MS 26929, and New York, Jewish Theological Seminary, MS 2203.

${ }^{21}$ A unit of production is any codicological unit conceived of and copied as an independent physical object. Once copied, a unit of production can circulate alone or together with other units of production, and then becomes a unit of circulation, that is, one or a group of several codicological units that circulate independently.
} 
in Sicily, thanks to the figure of Abraham Abulafia. ${ }^{22}$ Instead, we should probably conclude, as Idel has proposed, that it is the encounter of the Sephardic elites with new cultural, social, and economic realities that provoked a reaction which included, among other things, the preservation of the Sephardic legacy before the expulsion, within which the Castilian Kabbalistic tradition occupied an important place. ${ }^{23}$ This idea of preservation is then understood as a reaction to the encounter of two cultural traditions - the Sephardic and the Italian - as a response to the challenge produced by cultural contact. To this idea should be added the notion of mobility, which is one of the crucial causes of cultural contact and intellectual encounters in early sixteenth-century Italy. Indeed, the mobility of Jewish intellectuals was facilitated by the dispersion of Jewish communities in exile, a situation originating in Antiquity and reinforced in the Middle Ages by successive migrating movements related to plagues, persecutions, and expulsions. This geographical dispersion, far from preventing contacts between Jewish communities, served as a crucial factor in fostering mobility and encounters between individuals and groups of different Jewish communities who shared the same beliefs and the same canonical writings. Thus mobility caused cultural contact, provoking a reaction which, within the Kabbalistic lore produced by Sephardic circles in Renaissance Italy, meant preservation.

\section{EI Escorial, Real Monasterio de San Lorenzo, MS G-III-14}

The second manuscript comprises Kabbalistic works gathered in a single volume, written in various hands. It is also of small format, measuring approximately $210 \times 150 \mathrm{~mm}$., although the size of the folios varies slightly throughout the codex. The diversity of paper used is evident from the different watermarks, among which six varieties may be discerned. ${ }^{24}$ The quire composition in this manuscript is very irregular. There are quires of four, six, and even eight bifolia, and single leaves have been added to some of the quires. A detailed analysis of these pages, including their scripts and the disposition of the texts, reveals the existence of seven different codicological units or booklets in this volume.

The first booklet consists of a quaternion preceded by a single leaf, and a quinion preceded by two single leaves attached to it $(\mathrm{IV}+1+\mathrm{V}+2)$. This scribe wrote a colophon at the end of each work he copied, a total of three in this volume, falling within two codicological units, indicating the date of the copy and adding a rubric with his name. In the colophon at the end of this unit (fol. 22v), ${ }^{25}$ he states that the copy was made in 1532. This unit contains two versions of a Kabbalistic work entitled Sefer ha-yashar by an unknown author. The first version is incomplete and lacks eight folios at the beginning, according to the Hebrew foliation that numbers folio 1 with the letter $v$. This version finishes at fol. $8 \mathrm{r}$, and the second version of the work begins there and continues until fol. $22 \mathrm{v}$.

The second booklet is situated between fols. 23 and 30, and consists of a single quaternion (IV). The scribe is different from the previous one, and the work we find here,

\footnotetext{
${ }^{22}$ See Moshe Idel, Messianic Mystics (New Haven, 1998), 58-60.

${ }^{23}$ See Moshe Idel, "On Mobility, Individuals and Groups: Prolegomenon for a Sociological Approach to Sixteenth-Century Kabbalah," Kabbalah. Journal for the Study of Jewish Mystical Texts, 3 (1998): 145-173.

${ }^{24}$ These watermarks show: a pair of scissors, apparently without any additional motif; a triple mount, apparently without any additional motif; a mermaid with two fins; a tower-column with a small cross above; scales (balances) in a circle, apparently with round scales; and a glove with cuff, without any other apparent additional motif. The most important two repertoires of watermarks on medieval and early modern paper, namely Briquet and Piccard, are available online: http://www.ksbm.oeaw.ac.at/_scripts/php/BR.php and http://www.piccardonline.de/start.php respectively.

${ }^{25}$ MS G-III-14, fol. 22v: נשלם ביום חמישי בר"ח אדר בכ"ב בו בשנת הרצ"ב ליצירה וכתבה [חתימה.
} 
entitled Sha 'ar ha-shamayim, is the first book written in Hebrew by Yitzhak ben Abraham ibn Latif, in $1238 .^{26}$

The third booklet, consisting of a single quire of six bifolia (VI), was copied by two different scribes: one used Sephardic script while the other used Italian script. There is no doubt, however, that the scribes worked together, since there is enough evidence to show that they took turns copying the different works. ${ }^{27}$ In this section at least, it would be difficult to believe that no patron commissioned the work, since two scribes are working in collaboration. If it had been a copy for the scribe's own use, we would expect only one hand.

The works in this unit are of a mystical-Kabbalistic and astrological character. In particular, we find (fols. 31r to 33v) an astrological work entitled Sefer mar'ot Elohim, by an unknown author, which is in fact a commented paraphrase of the Reshit hokhmah by Abraham ibn Ezra. This work is followed on fols. 34r to 36r and fols. 40r to 42v by excerpts from Haye ha-nefesh, by Abraham ben Shemuel Abulafia. ${ }^{28}$ Along with these works, this unit also contains (fols. 36r to 37r) a text about the theory of the ten sefirot entitled Sitre torah, attributed to Yaakov ben Yaakov ha-Kohen. ${ }^{29}$ Lastly, on fols. $37 \mathrm{v}$ to $39 \mathrm{r}$ of this unit, there is an excerpt from an incomplete astrological treatise. ${ }^{30}$

The fourth booklet consists of three quires: a sexternion to which a single leaf has been added, a quaternion with another added leaf, and another sexternion, also with an added leaf $(V I+1+I V+1+V I+1)$. This unit extends from fol. 43 to fol. 77 and the scribe, who is different from previous scribes in this volume, writes in a semi-cursive Sephardic script. There are five different texts in this section. Between fols. $43 \mathrm{r}$ and $52 \mathrm{r}$ there is a copy of a work entitled Sefer ha-temunah, by an unknown author, which discusses the shape of the letters in the Hebrew alphabet and includes a Kabbalistic commentary on the importance of those forms. ${ }^{31}$ It is followed (fols. 52r to 60v) by a copy of the Sod eser sefirot belimah by Moshe de León, the exact same text as the one in MS G-IV-10, previously discussed. There is then a series of homiletic texts between fols. $60 \mathrm{v}$ and $62 \mathrm{r}$, including excerpts from the Midrash, followed (fols. 62r to 65v) by an excerpt of the Kabbalistic responsa between Yitzhak ben Shemuel of Acre and Moshe de León. ${ }^{32}$ The last work to be included in this unit (fols. 66r to 77v) is entitled Sheva netivot la-torah, by the above-mentioned Abraham Abulafia.

The fifth booklet extends from fols. 79 to 123 and consists of two quaternions and two quires of eight bifolia each; two folios are missing in the last quire (IV + IV + VIII + VIII -2). In this unit-there are excerpts from two parts of the Zohar: one from the Zohar Hadash to Lamentations (fols. 79r to 88v), and the other from the Zohar to Leviticus and Exodus (fols.

\footnotetext{
${ }^{26}$ This author, who lived in thirteenth-century Toledo after it was taken by the Castilians, was educated within a Jewish-Andalusi cultural background.

${ }^{27}$ The fact that one scribe wrote in Sephardic script and the other in Italian does not automatically mean that the latter was of Italian origin and not Sephardic. Scribes may retain their native script for a long time, or adjust their hands to the needs of local consumers by copying in the local script; see Malachi Beit-Arié, Hebrew Codicology (Jerusalem, 1981), 107-110.

${ }^{28}$ See note 22. This thirteenth-century Kabbalist from Zaragoza was the founder of the so-called ecstatic and prophetic Kabbalah, which reflects a certain inclination towards a messianic discourse and is clearly connected to Islamic sufism. Haye ha-nefesh is part of a Kabbalistic commentary on Maimonides's Moreh nebukhim.

${ }^{29}$ An author born in Soria in the mid-thirteenth century who spent a large part of his life in Provence. Sitre torah is likely to be a part of his larger work Sefer ha-Orah, in which he shows certain influences of the Central European mystic trends of the Haside Ashkenaz.

30 This treatise begins on fol. 37v: על הכוכבים הנראים ברקיע ואינם כוכבים; on fol. 39r, the scribe indicates: לא מצאת יותר i.e., "I did not find anything else".

31 According to Idel, "On Mobility," 156, the presence of this work in a Sephardic manuscript is enough to date it after the 1492 expulsion, as the work was not known in Spain before that date.

${ }^{32}$ Yitzhak ben Shemuel of Acre, born in Palestine, arrived in the Iberian Peninsula in 1305, and in Valladolid met Moshe de León, with whom he engaged in correspondence in the form of Kabbalistic responsa.
} 
89r to $123 \mathrm{r}$ ). ${ }^{33}$ The scribe of this unit is the same one who copied the first, a fact that we learn from the colophons added at the end of each text, both of which are followed by a rubric with his name. Since this scribe appears in two different sections, and is the only one in this manuscript who has left written colophons, it is worth pausing for a moment to consider some of his characteristics. In the colophon that he wrote on fol. $88 \mathrm{v}$, the scribe mentions the date of the copy, $1533,{ }^{34}$ after which he added a note requesting collaboration and forgiveness from the educated reader who might find mistakes in the copy:

He who finds mistakes in it [the manuscript] may he correct it, with the help and piety of God, because it has been copied from a model that is full of mistakes.

The second colophon (fol. 123r) is not dated, though it may be inferred that the date is the same (1533). ${ }^{35}$ A special mention of concern for the scribe's welfare, frequently found in manuscripts of the time, is added at the end: ${ }^{36}$

Keep this scribe safe from harm until [the day] a donkey climbs the ladder dreamt of by our father Jacob.

The three colophons written by this scribe (fols. $22 \mathrm{v}, 88 \mathrm{v}$, and $123 \mathrm{r}$; see figs. 3 , 4, and 5) are all accompanied by rubrics, which undoubtedly represent the same name. The first word should be read Abraham (shortened in the rubric on fol. 22v). It is followed by the ב"ר (son of Rabi ... ) on fol. 22v, and by בכ"ר (son of our honourable Rabi ... ) on fols. $88 \mathrm{v}$ and $123 \mathrm{r}$. Following this, there is a name or a patronymic, which I have not been able to decipher. After the abbreviations זלה"ה (may (of blessed memory; on fol. 22v) or his memory be preserved in the life of the world to come; on fols. 88v and 123r), there are a few letters that seem to form the word ידעי[ה] (fols. 88v and 123r). This could indicate the name Jedayah or a way of saying that the following word is a nickname or a non-Hebrew name. Unfortunately, this last word is still to be deciphered, and we can only affirm that the name of this scribe was Abraham.

The sixth booklet (fols. 124 to 141) consists of a quire of eight bifolia (VIII), and is in a semi-cursive Sephardic script. It contains a work entitled Masoret; possibly the Masoret haberit by David ben Abraham ha-Laban, although this cannot be confirmed definitively until the text is collated.

The seventh and last unit (fols. 142 to 150), a quaternion to which a loose leaf has been added at the end $(\mathrm{IV}+1)$, is written in either an Italian or an Oriental script, and probably dates from the fifteenth century. The text here consists of excerpts from liturgical commentaries referring to the recitation of certain prayers and blessings.

What we have seen in the different booklets suggests various possible conclusions regarding their material, cultural, and textual aspects. First of all, the physical differences in the paper, composition, measurements, and scripts of the booklets lead us to think of them as discrete units of production and to conjecture that they may have circulated independently

\footnotetext{
${ }^{33}$ Before the Zohar was printed in Italy in the late 1550 s it was popular there only among Sephardic Jews. See Bonfil, Rabbis, 279.

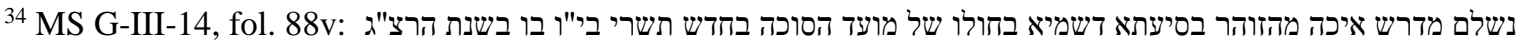

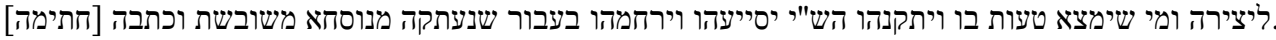

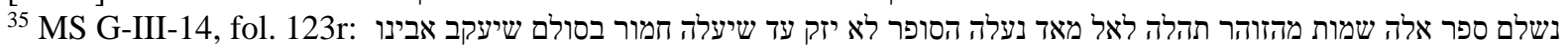
לא חלם כתיבת יד [חתימה

${ }^{36}$ Among the manuscripts at the libraries in Madrid and El Escorial this formula is also found in the colophons of the following codices: San Lorenzo de El Escorial, Biblioteca del Real Monasterio, MS G-III-16; Madrid, Biblioteca Nacional de España, MS 5461; Madrid, Biblioteca Histórica de la Universidad Complutense, MS 10. The texts in the colophons are published in del Barco, 3: nos. 142, 112 and 36, respectively.
} 
before being gathered into the codex that has come down to us. ${ }^{37}$ This manuscript differs greatly from the one previously analyzed, which was a single unit structured in accordance with a plan devised beforehand by the scribe or a patron. Secondly, the different works and extracts it contains reflect a Sephardic cultural background perfectly congruent with that of early sixteenth-century Italy. The manuscript is not only Sephardic in the features of its script, but also in its choice of texts, in which the concepts of preservation and mobility emerge once more as significant factors. The notion of preservation is evident in the way it copies and seeks to make known the works and classic authors of the Castilian Kabbalah, especially of the thirteenth century: the Zohar, Moshe de León, Abraham Abulafia, Yitzhak ibn Latif. Merged with this are ideas of contact, produced by mobility, and hybridity. This last, a biological term particularly used in postcolonial studies, is especially helpful to understand the process of cultural interchange that emerged after the massive arrival of Sephardic Jews in Italy at the end of the fifteenth century. The cultural products that resulted from such contact could be described as hybrid, in that elements from different traditions are combined and mixed, consciously or unconsciously. The term does not distinguish which elements are more powerful in the resulting combination or which tradition is stronger in the process of cultural negotiation, but it permits us to identify which elements belong to each of the cultural traditions. Hybridity is a process of cultural interchange more than a resulting state, as it describes what happens before those elements are transformed into a new reality and become a new system of cultural references. It is therefore a suitable concept to describe Sephardic manuscript culture in Renaissance Italy, especially in the first half of the sixteenth century. ${ }^{38}$ The presence of the Sefer ha-temunah in the fourth booklet, unknown in the Iberian Peninsula before 1492, or the collaboration of scribes with different types of scripts, as occurs in the third, can only be explained in these terms, at a moment where cultural interchange between two different traditions is still in process.

Apart from the identification of the manuscript as a hybrid artifact, the copy of texts like those we find in this manuscript reflects the important impact of the mobility of the Sephardic communities, a point more evident in the Kabbalistic lore, as set forth by Bonfil in a statement regarding the effect of Sephardic culture on Italian Kabbalistic circles:

... one may consider the process of transformation which began to occur during the first half of the sixteenth century, and which reached its apex with the publication of the Zohar in the late 1550s, as a direct result of the contribution to the study of Kabbalah in Italy by rabbis who came from the sphere of influence of Spanish and Provençal Jewry ... . ${ }^{39}$

\section{The unknown compiler}

Although the textual analysis of the two manuscripts offers us a result in which they can be considered cultural products responding to similar problems and situations, the same cannot be said when it comes to factors of material production and composition. What follows will focus on the circumstances surrounding the composition of the second codex as it is preserved today.

Despite the undeniable thematic links among the various works that compose MS GIII-14, the inclusion and ordering of these works within it do not reflect an agenda predetermined by a scribe or a patron, as was the case in the first manuscript. Most of the

\footnotetext{
37 The heterogeneous character of both the quires and the paper, the correspondence between work and scribe and the fact that the change of scribe always corresponds to a change of work and a change of quire, are all factors supporting this hypothesis.

${ }^{38}$ For the concept of hybridity in analyses of cultural history, see especially Peter Burke, Cultural Hybridity, Cultural Exchange, Cultural Translation: Reflections on History and Theory (Cambridge, Mass., 2010).

${ }^{39}$ Bonfil, "Rabbis," 279.
} 
texts are works on Kabbalah and mysticism or are related to the Kabbalah, and nearly all are works by Castilian Kabbalists or by Kabbalists who worked in Castile between the thirteenth and fourteenth centuries, such as Moshe de León, Abraham Abulafia, Yitzhak ben Abraham ibn Latif or Yitzhak ben Shemuel of Acre. Nevertheless, the individual units were not copied with the idea of composing a miscellany of Kabbalistic works, but were copied independently and circulated separately before being gathered into a single volume. Can we discover traces of the person who brought all the units together, and determine when and why he did it?

The idea of composing a miscellany of Castilian Kabbalistic works arose a posteriori and was the result of a reader's conception, rather than a scribe or patron's intention. The units could have been separate quires for personal use or working copies belonging to the scribes themselves or to others. The reason for assembling them could be, on the one hand, for preservation of the Sephardic legacy in the field of the Kabbalah. The gathering of the different units could have occurred at some point between being copied in the second quarter of the sixteenth century, and the end of the sixteenth century, when the manuscript (or parts of it) arrived in Spain. On the other hand, it is also possible that someone in Spain gathered together the different texts because of their thematic relationship. If this were the case, these units may have arrived separately at El Escorial, or they could have been quires that came from other manuscripts affected by the fire that took place in El Escorial in 1671. In any case, the resulting manuscript was definitively bound in the eighteenth century.

It is more probable, however, that the texts were assembled in Italy. Knowledge of the Hebrew language and Hebrew paleography among the monks in eighteenth-century El Escorial was very limited, as revealed by the various leaves and quires bound into manuscripts to which they had never belonged. Moreover, codicological evidence supports the hypothesis of the manuscript's Italian composition. First of all, it was foliated with Hebrew letters throughout, starting on the first folio with the letter $v$. While this foliation contains some mistakes, it is proof of the order of quires established by a Jewish owner at some time after 1533, since this is the most recent date specified in one of the colophons.

A second clue is folio 78, a separate paper leaf, on which is reproduced the end of a poem transcribed on the neighboring fol. $77 \mathrm{v}$ as a writing exercise (probationes calami). The individual who copied this text used a sixteenth-century Italian script, very similar, in my opinion, to that of the Hebrew foliation. What's more, on fol. 124r, originally left blank, the same hand transcribed the titles מסורת זוהר ראשון מדרש איכה זוהר אחרון, referring to the works that appear in the units preceding and following this folio.

It was thus most likely an Italian Jew of Sephardic origin who was responsible for the format of MS G-III-14. This educated person lived in the second half of the sixteenth century, gathered together the different texts, arranged them in the order in which they are found today, and foliated the whole manuscript with Hebrew letters. He included a piece of paper on which he had made pen trials (currently folio 78), possibly left by mistake, and wrote down on fol. 124r the title of the works that preceded and followed this page. The manuscript arrived at El Escorial in this state in 1599, after having been previously acquired by Benito Arias Montano in Italy. The codex was most likely unbound or had a simple binding made of parchment. It was not until the eighteenth century that it was provided with a more durable binding, made in El Escorial.

\section{Conclusions}

El Escorial MSS G-IV-10 and G-III-14 were conceived for the same purpose but were produced differently. In the first, the choice of works and their ordering in the manuscript are intimately linked to the world of the Sephardic communities in Italy in the first half of the sixteenth century. The same person who planned the contents may also have produced the manuscript, as suggested by its regularity of composition and single scribal hand. In contrast, 
the texts of the second had circulated independently, before being selected for this compilation. Both manuscripts reflect ideas of preservation and hybridity, caused by mobility, with regard to the expulsion of Jews from the Iberian Peninsula and the encounter of Sephardic elites with a new political, social, and cultural reality.

Could we claim that these two manuscripts were representative of the cultural interests of the Renaissance Jewish communities of Italy? It is more probable that the idea of collecting and copying Kabbalistic texts in sixteenth-century Italy, especially during the first half of the century, was restricted to Sephardic circles. The absence of Kabbalistic works in a mid-fifteenth century book list from the town of Lecce in the south of Italy suggests that there was little interest as yet in this type of literature. ${ }^{40}$ Bonfil, after analyzing a large number of northern Italian book lists from the first half of the sixteenth century, found that few

Kabbalistic miscellanies had been produced before the middle of the century, when the Zohar was published, stimulating a new development and revival of Kabbalistic literature in the Italian communities. ${ }^{41}$

I think it sensible to conclude that within the framework of the cultural history of the Jewish communities of Italy, El Escorial MSS G-IV-10 and G-III-14 are hybrid products resulting from the encounter of Sephardic elites and Italian communities during the first half of the sixteenth century. This encounter was to cause a change in the direction of Kabbalistic literature in Italy because of the circulation and diffusion of works that were barely known in Italy before the arrival of Sephardic Jews. The impact of the new social and cultural ambiance upon Sephardic circles not only encouraged the production of this type of miscellany, but also affected the reading and circulation of works in Renaissance Italy.

\footnotetext{
${ }^{40}$ Menahem Schmelzer, “A Fifteenth Century Hebrew Book List,” Studies in Bibliography and Booklore 20 (1998): 89-98.

${ }^{41}$ Bonfil, "Rabbis," 278-79.
} 